\title{
Basic prerequisites for technical inspection of cast-iron lining elements in the construction of Moscow Metro facilities
}

\author{
Dmitriy Topchiy ${ }^{1,}$, Alexey Yurgaytis ${ }^{1}$, Julia Sayadova ${ }^{2}$, Andrei Shinkarenko ${ }^{3}$ \\ ${ }^{1}$ Moscow State University of Civil Engineering, 26 Yaroslavskoye Shosse, Moscow, 109377, Russia \\ ${ }^{2}$ MISIS National University of Science and Technology, 4 Leninsky Prospekt, Moscow, 119049, \\ Russia \\ ${ }^{3} 11^{\text {st }}$ Grade Engineer, JSC EVRAZ Vanadiy, Tula, Russia
}

\begin{abstract}
Dynamic expansion of the extensive network of facilities of the Moscow Metro prompts the development of relevant control techniques that would facilitate the commissioning of transport and related facilities in a timely manner and at an appropriate quality level subject to the effective safety and reliability legislative requirements. This article describes the prerequisites for development of comprehensive technical inspection of metro facilities with reference to the supporting regulatory and technical base. The study primarily deals with the criteria, tolerances and control methods with respect to components of tunnel linings and other underground structures of rapid transit systems due to the apparent great significance of these structures in ensuring safety and reliability of future facilities after commissioning. Arguments are also given for the need for such technical surveying with account of the current situation in terms of the quality of prefabricated linings supplied and used in metro facilities.
\end{abstract}

\section{Introduction}

Experience shows that the problem of passenger flow mobility in a modern megalopolis with a population of over one million people can be successfully solved by a rapid transit system (see Table 1).

Table 1. Main advantages of rapid transit systems as compared with other means of communication and passenger flow mobility in megalopolises with a population of over one million people.

\begin{tabular}{|l|l|}
\hline No. & \multicolumn{1}{|c|}{ Rapid transit system advantages } \\
\hline 1. & High passenger carrying capacity \\
\hline 2. & High communication speed \\
\hline 3. & Traffic regularity \\
\hline 4. & High reliability as compared with ground transport \\
\hline 5. & Rapid transit system facilities can be used for military purposes \\
\hline 6. & $\begin{array}{l}\text { Rapid transit system facilities can be used for civil defense purposes in } \\
\text { emergencies }\end{array}$ \\
\hline
\end{tabular}

\footnotetext{
* Corresponding author: aljurgaitis@gmail.com
} 


\begin{tabular}{|l|l|}
\hline 7. & $\begin{array}{l}\text { Environmental protection due to the use of environment-friendly resources } \\
\text { (electric transport) }\end{array}$ \\
\hline 8. & High technological level (technological and engineering advances) \\
\hline 9. & $\begin{array}{l}\text { High architectural and artistic level (many stations are protected monuments of } \\
\text { architecture and art of construction) }\end{array}$ \\
\hline
\end{tabular}

\section{Materials and methods}

The geography of rapid transit systems as one of the primary means of passenger flow mobility is extensive (see Tables 2 and 3 ). The countries mentioned in these tables provide for solutions to transportation problems at the overall planning stage (master plan development) in their megalopolises by designing an expanded underground transportation network.

Table 2. The world's largest and oldest rapid transit systems with account of the highest values of a parameter (number of stations, length of lines, annual passenger flow, etc.).

\begin{tabular}{|c|c|c|c|c|c|c|c|}
\hline No. & Country & City & $\begin{array}{c}\text { Year of } \\
\text { commissioning } \\
\text { of the first } \\
\text { lines }\end{array}$ & \begin{tabular}{|} 
Number \\
of \\
stations \\
currently
\end{tabular} & \begin{tabular}{|c|} 
Number \\
or routes \\
(lines) \\
currently.
\end{tabular} & $\begin{array}{c}\text { Length of } \\
\text { lines } \\
\text { currently, } \\
\text { km }\end{array}$ & $\begin{array}{c}\text { Annual } \\
\text { passenger } \\
\text { flow as of } \\
\text { 2016, million }\end{array}$ \\
\hline 1. & USA & New York & 1868 & 472 & 36 & $1,370.0$ & $1,756.8$ \\
\hline 2. & USA & Chicago & 1892 & 145 & 8 & 360.7 & 221.0 \\
\hline 3. & Japan & Tokyo & 1927 & 285 & 13 & 304.1 & $3,616.0$ \\
\hline 4. & China & Beijing & 1969 & 370 & 22 & 608.2 & $3,660.0$ \\
\hline 5. & China & Shanghai & 1993 & 393 & 16 & 660.0 & $3,401.0$ \\
\hline 6. & Mexico & $\begin{array}{l}\text { Mexico } \\
\text { City }\end{array}$ & 1969 & 195 & 12 & 225.9 & $1,685.0$ \\
\hline 7. & Korea & Seoul & 1974 & 429 & 18 & 975.4 & $2,560.0$ \\
\hline 8. & France & Paris & 1900 & 383 & 16 & 219.9 & $1,506.0$ \\
\hline 9. & $\begin{array}{l}\text { Russian } \\
\text { Federation }\end{array}$ & Moscow & 1935 & 214 & 14 & 364.9 & $2,378.3$ \\
\hline 10. & $\begin{array}{l}\text { Russian } \\
\text { Federation }\end{array}$ & $\begin{array}{c}\text { Saint } \\
\text { Petersburg }\end{array}$ & 1955 & 69 & 5 & 118.6 & 740.4 \\
\hline 11. & $\begin{array}{c}\text { Great } \\
\text { Britain }\end{array}$ & London & 1863 & 270 & 11 & 402.0 & $1,260.0$ \\
\hline 12. & Germany & Berlin & 1902 & 173 & 10 & 151.7 & 493.3 \\
\hline
\end{tabular}

Table 3. Main characteristics of the first rapid transit system (London, Great Britain).

\begin{tabular}{|l|l|l|}
\hline \multicolumn{1}{|c|}{ No. } & \multicolumn{1}{|c|}{ Description } & \multicolumn{1}{c|}{ Value } \\
\hline 1. & Opening (commissioning) date & 10 January 1863 \\
\hline 2. & Country / City & Great Britain / London \\
\hline 3. & Length, km & 6 \\
\hline 4. & Developer & Metropolitan Railway \\
\hline 5. & Driven by & Steam \\
\hline
\end{tabular}

Sustainability of equilibrium of the soil mass, the integrity of which is disrupted by tunneling technologies (for example, shield driving) can be ensured by dome-shaped structural units made of various materials that take compression and tension stresses off the soil mass at the point of contact with the selected tunnel cavity (see Table 4, fig. 1, 2). 


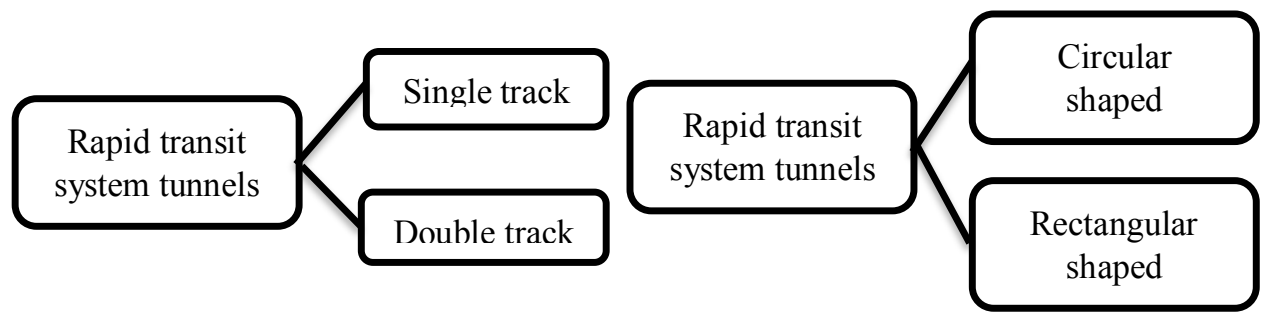

Fig.1. Tunnels classified by the number of tracks and structural form in the internal space

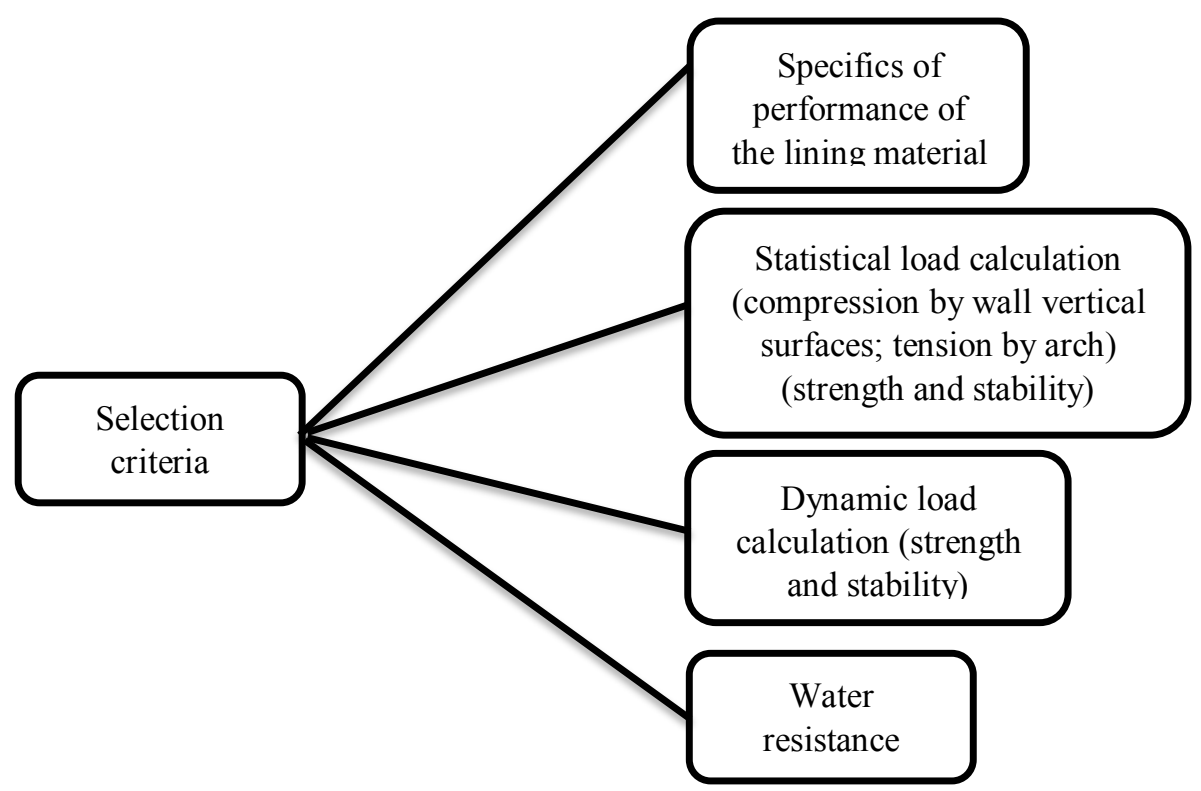

Fig. 2. Selection criteria for structural elements of the arch of an engineered underground facility (tunnel).

Table 4. Types of lining of soil arches in underground facilities.

\begin{tabular}{|l|l|l|}
\hline No. & \multicolumn{1}{|c|}{$\begin{array}{c}\text { Lining by type of principal structure concept } \\
\text { (construction technology) }\end{array}$} & \multicolumn{1}{|c|}{ Lining by type of material } \\
\hline 1. & Cast-in-place & $\begin{array}{l}\text { Concrete, reinforced concrete, } \\
\text { steel concrete, shotcrete, } \\
\text { torcrete, polymer concrete [1] }\end{array}$ \\
\hline 2. & Precast & $\begin{array}{l}\text { Concrete, reinforced concrete, } \\
\text { steel concrete, cast iron, steel, } \\
\text { etc. }\end{array}$ \\
\hline 3. & Precast and cast-in-place & - \\
\hline 4. & Cast & Cast rock [1] \\
\hline
\end{tabular}

Cast-in-place lining of underground facilities was used in the first rapid transit projects, while now prefabricated reinforced concrete and cast iron components are considered a more advanced technology. Unstable, water-saturated soils and sites exposed to freeze-thaw temperatures predominantly require cast iron lining with lead cord joint caulking [1]. In addition, the cast iron lining technology is the most proven technology of contemporary 
metro engineering [2]. In practice, the Customer has to perform some additional activities when using cast iron liners due to specifics of construction material of the products and some other circumstances currently prevailing at construction sites of the Moscow Metro. In fact, cast iron lining experience of underground projects suggests the possibility of using second-hand cast iron lining components in permanent tunneling operations (for example, as temporary support for mounting or dismounting chambers of tunneling shield equipment). The State Construction Surveillance Committee of Moscow officially allows such engineering solutions to economize substantially on new materials due to a limited number of available suppliers of cast iron liners for rapid transit system facilities (for example, for geopolitical reason). Taking into account lengthy transportation, storage and possible damage of fragile cast iron in delivery to the site of installation, second-hand cast iron liners may be used exclusively after a technical inspection of the lining components in order to verify their physical and technical specifications.

\section{Results and discussion}

As noted earlier, the basic requirements to tunnel lining can be formulated as follows: lining must be sufficiently stable and strong to take permanent and temporary loads, including shield jack pressure; it must also be waterproof and durable, and its components must be interchangeable. In the case of second-hand cast iron liners these requirements can be met subject to preventing critical defects arising at any stage of the entire life cycle of the product (see fig. 3) and determined by specific features of cast iron as a construction material for lining components.

Defects, including hidden ones and those, which are not detected visually by superficial (visual) inspection, may potentially develop at any stage of the said life cycle of the products. This is particularly relevant in the case of re-use of cast iron products due to additional stages in the cycle chain and, accordingly, a higher risk of defect formation. Formation of hidden defects (for example, micro cracks) caused by a failure to conform to the technologies of manufacturing, transportation, installation or dismantling works or inappropriate operating conditions is primarily determined by specific metallurgical, physical and chemical properties of the material. [3]

Cast iron is an alloy of iron with carbon and other chemical elements. The carbon content in cast iron exceeds $2.14 \%$. Carbon enhances the hardness of cast iron, but reduces its plasticity and ductility. Cast iron can be classified according to the following basic properties: by carbon condition; by carbon spot form; by type of metal base structure; by chemical composition.

Depending on the carbon deposition form, the following varieties of cast iron can be identified: white cast iron; molted cast iron; grey cast iron; high-strength cast iron; chilled cast iron; malleable cast iron [4].

Pursuant to GOST R 57054-2016, liner plates used in tunneling operations are made of grey cast iron of SCh20, SCh25 and SCh30 grades (pearlitic cast iron). Excavation projects in severe mining conditions must be lined with plates made of high-duty cast iron of VCh45 grade (pearlitic cast iron with spherical graphite) [5].

Grey cast iron is a Fe-C-Si alloy that contains such admixtures as manganese, phosphorus and sulfur. Carbon is contained in grey cast iron predominantly in the form of flake graphite.

The mechanical properties of grey cast iron depend on the properties of the metal base, and the form and dimensions of graphite inclusions. The properties of the cast iron metal base are close to those of steel. The metal base can be ferrite, ferrite-pearlite or perlite. Perlite-based grey cast irons are the strongest. 
As compared with the metal base, graphite's strength is negligible, and accordingly, at a first approximation, graphite inclusions can be equated with "voids or cracks" reducing the cast iron strength. The fewer graphite inclusions and the higher their dispersion, the stronger the cast iron is.

Graphite inclusions lead to a lower ultimate tensile strength, but do not actually affect the compression strength or hardness of cast iron.

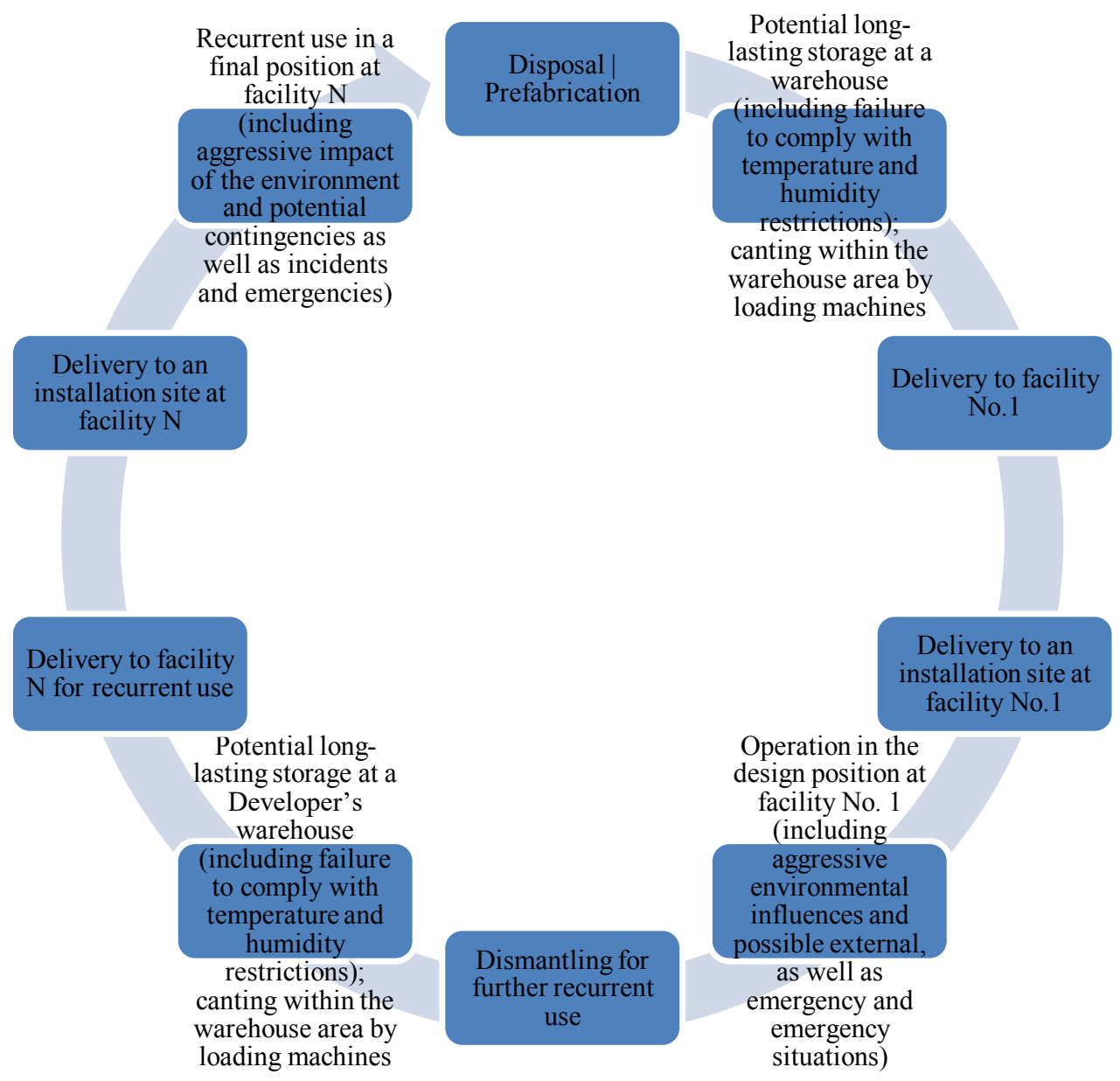

Fig. 3. Life cycle of second-hand prefabricated cast iron lining at project $\mathrm{N}$.

High-strength cast iron is a grey cast iron with a perlite metal base and ball-shaped graphite precipitation. Rounded ball-shaped graphite inclusions do not create any sharp stress concentration and are not "voids or cracks", thus ensuring a higher tensile and bending strength of the ball-shaped graphite cast iron as compared with the flake graphite cast iron [6].

Graphite gives cast iron certain advantages over steel:

Ease of cutting;

Enhanced wear resistance and antifriction properties;

Fast suppression of vibration and resonant vibrations; 
By disrupting the metal base continuity, graphite makes cast iron tolerant to various external stress concentrators like surface imperfections, notches, grooves, etc. As a consequence, grey cast iron is characterized by roughly the same structural strength both in plain shape or smooth surface casting products and in irregular shape casting products with a cut or a poorly treated surface;

Cast iron exceeds steel in terms of foundry properties as it has a better flowability and form filling capacity;

Cast iron is more resistant to corrosion than steel [7].

Apart from the metal base characteristics, the form and dimensions of graphite inclusions, the mechanical properties of cast iron are affected by admixtures like silicon, manganese, sulfur and phosphorus. Their presence in the metal is determined by the iron melting technology. The silicon, manganese and sulfur content in cast iron can be controlled both by the melting process and the burden composition as the sulfur content in cast iron depends on its content in the initial burden only.

From the point of view of mechanical properties, phosphorous is an unwelcome admixture that makes a significant impact on the structure and mechanical properties of cast iron by reducing its plasticity and increasing its cold brittleness. Phosphorous content in a high-strength high-plasticity cast iron may not exceed $0.08 \%$. However, phosphorous improves the casting properties of cast irons ensuring their better flowability.

Cast iron is susceptible to brittle fracturing. Phosphorous makes cast iron lining sensitive to crack formation in storage, loading and transportation at negative temperatures.

Lining used under loads that are considerably lower than the design loads can develop cold cracks caused by residual tensions in a casting product. In fact, cold cracks can develop with no external impacts in cleaning, transportation or mechanical treatment.

The probability of cold crack development depends on the casting product loading conditions, the intensity of residual tensions therein, and plastic and strength properties of alloys. The lower metal strength or plasticity, the greater the probability of cold crack development is. For this reason, cold cracking is more probable in iron casting products than in steel [8].

Pursuant to GOST R 57054-2016, no operational limit state is determined for linings, and its failure criterion is partial or complete rupture of the liner [9]. However, in the course of storage, transportation or installation, operation, further dismantling and repeated transportation or storage lining elements may develop cold cracks, micro cracks or subcritically grown cracks [10-15].

\section{Conclusion}

Summing up the above, reuse of cast iron linings with account of the properties of the feedstock and their storage, operation and installation conditions requires an assessment of their suitability for use (technical condition) by up-to-date methods of detecting casting product imperfections in the process of integrated engineering survey of underground facilities of rapid transit systems with a view of suppressing the development of latent defects (and their transition to the state of critical defects) and ensuring improved safety and reliability of rapid transit projects commissioned in Moscow, the Russian Federation and worldwide.

\section{References}

1. P. Oleinik, A. Yurgaytis, MATEC Web of Conferences 117, 00130 (2017) https://doi.org/10.1051/matecconf/201711700130D. 
2. Topchiy, A. Shatrova, A. Yurgaytis, MATEC Web of Conferences 193, 05032 (2018) https://doi.org/10.1051/matecconf/201819305032

3. D. Topchiy, E. Kochurina, MATEC Web of Conferences 193, 05012 (2018) https://doi.org/10.1051/matecconf/201819305012

4. W. Bozejko, Z. Hejducki, M. Uchroński, M. Wodecki, Journal of Civil Engineering and Management 20 (2014) DOI: 10.3846/13923730.2014.906496

5. D. Topchiy, A. Tokarskiy, MATEC Web of Conferences 196(1), 04029 (2018) https://doi.org/10.1051/matecconf/201819604029

6. M. Rogalska, W. Bozejko, Z. Hejducki, Automation in Construction 18, 24-31 (2008)

7. W. Bozejko, Z. Hejducki, M. Uchroński, M. Wodecki, Journal of Civil Engineering and Management 20(5), 649-659 (2014)

8. M. Rogalska, Z. Hejducki, Journal of Civil Engineering and Management 5, 7858 (2005)

9. P. Oleinik, A. Yurgaytis, MATEC Web of Conferences 117, 00130 (2017) https://doi.org/10.1051/matecconf/201711700130

10. M. Rogalska, W. Bozejko, Z. Hejducki, Automation in Construction 18, 24-31 (2008) doi:10.1016/j.autcon.2008.04.002

11. W. Bożejko, A. Gnatowski, J. Pempera, M. Wodecki, Computers \& Industrial Engineering 113, 512-524 (2017)

12. D.V. Rosato, D.V. Rosato, Reinforced Plastics Handbook (Third Edition) (2005)

13. L. Wong, S. Rathnayaka, W. K. Chiu, J. Kodikara, Procedia Engineering 188, 293-300 (2017)

14. Zili Li, Kenichi Soga, Fei Wang, Peter Wright, Kiwamu Tsuno, Tunnelling and Underground Space Technology 41, 176-192 (2014)

15. J.C. Matthews, J.B. Nestleroth, W. Condit, Tunnelling and Underground Space Technology 77, 288-294 (2018) 